\title{
Evaluation of neuromotor development by means of the Harris Infant Neuromotor Test
}

\author{
AVALIAÇÃO DO DESENVOLVIMENTO NEUROMOTOR DA CRIANÇA POR MEIO DO \\ HARRIS INFANT NEUROMOTOR TEST
}

\author{
EVALUACIÓN DEL DESARROLLO NEUROMOTOR DEL NIÑO A TRAVÉS DEL HARRIS \\ INFANT NEUROMOTOR TEST
}

\section{Márcia Maria Coelho Oliveira Lopes', Maria Vera Lúcia Moreira Leitão Cardoso²}

\begin{abstract}
Objective: To investigate the neuromotor development of at-risk children between three and 12 months of life, administering the Brazilian version of the Harris Infant Neuromotor Test (HINT). Method: A longitudinal study, with 78 children and 76 parents/guardians discharged from a neonatal intensive care unit in Fortaleza-CE/ Brazil. Two instruments were administered: HINT and a socioeconomic questionnaire, between July/2009 to August/2010. Data from 55 preterm and 23 term children were analyzed. Results: The final mean scores ranged from 14.6 to 25.2 and from 11.2 to 24.7 , for preterm and term, respectively, showing that $91 \%$ of children demonstrated good neuromotor performance; seven premature infants showed alterations which led to the referral of three children to a specialized clinic for examination and diagnostics. Conclusion: The test allowed nurses to assess infant development, identify deviations early, and plan interventions.
\end{abstract}

\section{RESUMO}

Investigar o desenvolvimento neuromotor das crianças de risco, entre três e 12 meses de vida, aplicando o Harris Infant Neuromotor Test (HINT), na versão brasileira. Método: Estudo longitudinal, com 78 crianças e 76 pais/responsáveis egressos de Unidade de Terapia Intensiva Neonatal, em Fortaleza-CE/Brasil. Aplicaram-se dois instrumentos: HINT e questionário socioeconômico, de julho/2009 a agosto/2010. Analisaram-se 55 crianças nascidas prematuras e 23 a termo. Resultados: A média final dos escores variou de 14,6 a 25,2 e 11,2 a 24,7 , para os prematuros e a termo, respectivamente, mostrando que $91 \%$ das crianças evidenciaram bom desempenho neuromotor e sete, nascidas prematuras, apresentaram alterações, o que implicou encaminhamento de três crianças ao serviço especializado para exames e diagnósticos. Conclusão: 0 teste possibilitou aos enfermeiros avaliar o desenvolvimento infantil, identificar desvios precoces e planejar intervenções.

\section{DESCRITORES}

Prematuro

Desenvolvimento infantil

Avaliação

Testes neuropsicológicos

Enfermagem pediátrica

\section{RESUMEN}

Objetivo: Investigar el desarrollo neuromotor de los niños en riesgo entre tres y 12 meses de vida, por medio de la versión brasileña del Harris Infant Neuromotor Test (HINT). Método: Estudio longitudinal con 78 niños y 76 padres egresados de una Unidad de Cuidados Intensivos Neonatales en Fortaleza-CE, Brasil. Se aplicaron dos instrumentos: HINT y un cuestionario socioeconómico, entre los meses de julio de 2009 a agosto de 2010. Se analizaron 55 niños prematuros y 23 niños nacidos de término. Resultados: Las puntuaciones medias finales oscilaron entre 14,6 a 25,2 y 11,2 a 24,7 para los recién nacidos prematuros y de término respectivamente. El $91 \%$ de los niños mostraron un buen desempeño neuromotor y siete recién nacidos prematuros mostraron alteraciones, lo que implicó la derivación de tres niños a un servicio especializado para exámenes y diagnósticos. Conclusión: El test permitió a los enfermeros evaluar el desarrollo infantil, identificar precozmente la presencia de desviaciones y planificar intervenciones.

DESCRIPTORES
Prematuro
Desarrollo infantil
Evaluación
Pruebas neuropsicológicas
Enfermería pediátrica

Neurophychological tests

Pediatric nursing
Infant bpremature

Child development 


\section{INTRODUCTION}

Developmental monitoring of children who remain hospitalized in a neonatal intensive care unit (NICU) is essential, given that the conditions of birth, ambience, care and the prolonged hospitalization period are situations of risk and potential generators of neurological implications.

According to the affected needs of the newborn (NB), the therapeutic process is complex and dynamic, consists of installments of care permeated with technological innovations, such as mechanical ventilation, peripherally inserted central catheters, surfactant, medications, parenteral nutrition, among others, that make the chances of survival possible ${ }^{(1)}$.

This reality can lead to consequences for the development of the child, which drives the investigation of neonatal risks. Studies were conducted throughout the trajectory of growth and development of the child, during the significant increase of babies surviving in neonatal units $^{(1-2)}$. The incidence and magnitude of neurodevelopmental sequelae remain associated to risk factors and to critical progression ${ }^{(3)}$, such as with the relationship between hospitalization time in the NICU and motor development of the newborn, particularly the premature $\mathrm{NB}^{(4)}$. When the number of active risk factors is higher, there is a greater possibility of alterations in development ${ }^{(3)}$.

In the meantime, prematurity, low birth weight, cardiovascular, respiratory, neurological disorders and infections are considered to be the principal causes of motor delay. The problems relate to the organization and functioning of the central nervous system, whose neurological sequelae result in financial outlay for therapeutic services and special educational resources during school age ${ }^{(5)}$. Genetic and biological factors, sociodemographic conditions and schooling of parents can impact the infant evaluation ${ }^{(6)}$.

The literature addresses cross-sectional and longitudinal follow-up studies of children, in the investigation of medium and long term effects of neonatal risks on development $^{(4-6)}$. All in all, the progress of the child with developmental alterations depends on the knowledge of risk factors, diagnosis and interventions ${ }^{(3,5)}$, that, early on, contribute to the psychic life of the baby and to the relationships with the parents ${ }^{(7)}$.

Surveillance in the first years of life is pertinent, because it relates to the identification of specific characteristics of the population and possible deviations, in addition to contributing essential stimulation, when required. With that understanding, professionals consider the neonatal period critical and, in this mode, offer care for mitigation of adverse effects, enabling a better prognosis of health for the child.

In this sense, in service of the care of the child, professionals participate in and contribute to the evaluation of growth and development of the child, using as a tool the Health of the Child booklet, documenting that which is completed by the nurses.

At present, scales and standardized tests cited for evaluation of the development of the child and detection of deviations ${ }^{(5)}$ are administered by physicians, nurses, physiotherapists, psychologists, among others. Although they are not generally used in clinical practice in Brazil, the use of instruments is a challenge to the professional, as is the detection of signs of developmental delay in children ${ }^{(7)}$.

For this study, among the trends for infant evaluation, the decision was to use the Harris Infant Neuromotor Test (HINT), a relatively new test of Canadian origin $^{(8-9)}$, validated and administered in a Brazilian population, specifically in the northeastern region of Brazil, since $2007^{(4,6)}$. It is an instrument with emphasis on movement, skill acquisition, motor posture and muscle control. In addition, it includes issues of the family/primary caregiver, that emphasizes their opinion about the movements of the child ${ }^{(8)}$.

The performance of this study was justified, given the interest in the theme, with the following question: does the Brazilian version of the HINT permit the evaluation of neuromotor development of the at-risk child, between three and 12 months of age? The quest culminates in the expansion of knowledge about the development of the child, as well as in administration of the instrument to atrisk children, since the evidence shows the use of this test in low risk children ${ }^{(6,10)}$.

Therefore, monitoring the development of the child discharged from the NICU is considered relevant and essential, due to the numerous influential risk factors over the short and long term. In this sense, and aimed at the health promotion of the child with the administration of the HINT, the performance of the nurse is emphasized, whose early interventions can minimize, reverse and favor healthy development.

The objective was to investigate the neuromotor development of the child at risk, between three and 12 months of life, administering the Brazilian version of the Harris Infant Neuromotor Test.

\section{METHOD}

This was a longitudinal, quantitative study conducted in a large public institution in Fortaleza-CE, Brazil, with the approval of the Committee on Ethics in Research on Human Beings, on June 10, 2009, according to protocol 097/09.

The sample included 78 children and 76 parents/ guardians, using a consecutive convenience method, of premature children being discharged from the NICU, 
born between February and December of 2009, and of term children, born between April of 2009 and February of 2010. It is noteworthy that the number of children and responsible adults was not identical, because of two twin pregnancies. The following inclusion criteria were selected: discharged from the public NICU linked to the hospital complex of the Federal University of Ceará; gestational age (GA) $\geq 32$ weeks, independent of birth weight, type of delivery, singleton or twin, or other conditions that resulted in alterations of child development, such as children of drug addicted, teenage or older aged mothers. In addition, the addresses of those responsible had to be included in their respective geographical areas of the Regional Secretariats of Fortaleza, to enable, when necessary, the performance of home visits.

Data collection occurred between July of 2009 and August of 2010, with the scheduling of the child evaluation by the researcher, who contacted each parent/ guardian by phone. In advance, the chronological ages were calculated and corrected, to certify three months of life of each child.

The operationalization of data collection was comprised of the first, second, and third child assessments, in the presence of three examiners, nurses with skills in administration of the HINT. In the first evaluation, upon arrival at the Health Laboratory (LabCom_Saúde), the mother or legal guardian was presented the Terms of Free and Informed Consent (TFIC), and asked for their authorization to film the evaluation. After the consent, the introductory part of the HINT was completed, as well as the socioeconomic questionnaire, which contained sociodemographic variables of parents and neonatal data.

Thereafter, the evaluation of the child was conducted, individually, accompanied by the parent/guardian. We used colorful plastic toys, a red hoop and a black and white book, for evaluation of motor and visual skills of the child. During the child's movements, the examiners systematically observed and recorded the scores of the 21 items of neuromotor evaluation. The time of administration varied according to the age and progress of the child; in general, it lasted approximately twenty minutes.

Once the filming was completed and the video was produced, the same examiners analyzed images, thirty days later, with the goal of a new appreciation of the performance of the child and of intraclass reliability; this was considered the second evaluation. The Cronbach's Alpha was used, that ranged from 0.971 to 0.992 , evidencing more security in the designated scores.

Approximately sixty days after the first evaluation, the third was completed, requiring a shorter duration of time, because the child was approximately two months older and had better agility.
At the end of each evaluation, the points achieved were totaled and analyzed using the table of total scores of the HINT, which presents ten age groups, in the beginning with the variation of two months and 16 days to three months and 15 days, and the final with 11 months and 16 days to 12 months and 15 days. The table presents the following classifications of scores and values that vary from 0 to 76 : Advanced (0-33), Normal (0.5-44.5), Suspect (7.5 to 50) and Abnormal (10.5 to 76$)$. The lower the score, the better the result of neuromotor development ${ }^{(8)}$.

The information was compiled in Microsoft Office Excel 2007, in a worksheet, and later analyzed with the assistance of the Statistical Package for the Social Sciences (SPSS), version 18 . The results were submitted to statistical analysis of measures of central tendency (mean and median) and dispersion (standard deviation, variation coefficient). The evaluation of neuromotor development of the child proceeded to the analysis of the mean of the scores, with the Student T- test and, in comparison among groups (preterm and term infants), with the classification of scores of the HINT, the Likelihood Ratio test was used. We adopted the level of significance of less than $5 \%$ $(p<0.05)$. Thereafter, the analysis of data was based on relevant literature.

It is noteworthy that the scenario and the means required as a basis for the reasoning for this study were provided by the research projects of Validation of the Harris Infant Neuromotor Test in the Portuguese language, UFC/ $\mathrm{CNPq}$, and Use of technologies for evaluation and promotion of child health: focus on neuromotor and visual development, financed by CNPq.

\section{RESULTS}

In the first evaluation, 83 children and parents/guardians were evaluated; however, in the third stage, difficulties emerged in follow-up for the study. Despite confirmation and scheduling, six participants did not attend the evaluation, for whom a home visit was proposed. In addition, five participants could not be contacted, and were therefore lost for the research. Therefore, 78 children were submitted to the complete evaluation of neuromotor development, 48 (61.5\%) were male and 30 (38.5\%) were female; 74 (94.8\%) were singleton births; only four (5.2\%) were twins; 55 were classified as premature and 23 as term, according to birth.

Of the children, 58 were between five months and 16 days and six months and 15 days; 20 were in the range of six months and 16 days to 12 months and 15 days.

Tables 1 and 2 present the characteristics of the children, according to perinatal variables that revealed the conditions of birth and socioeconomic data of the parents/guardians. 
Table 1 - Characteristics of the infants, based on perinatal variables - Fortaleza, CE, 2010

\begin{tabular}{lccc}
\hline Variables (n=78) & N & \% & $\overline{\mathrm{X}} \pm \mathbf{D P}$ \\
\hline Type of delivery & 55 & 72.3 & \\
Cesarean & 21 & 27.7 & \\
Vaginal & & & \\
Apgar at 1 Minute & 47 & 60.3 & \\
$7-9$ & 20 & 25.6 & \\
$4-6$ & 11 & 14.1 & \\
$1-3$ & & & \\
Apgar at 5 Minutes & 63 & 80.8 & \\
$7-10$ & 15 & 19.2 & \\
$5-6$ & 39 & 50.0 & $36.15 \pm 2.92$ \\
Capurro method/Gestational age (weeks) & & \\
$32-34$ & 16 & 20.6 & \\
$35-36$ & 23 & 29.4 & \\
$37-41$ & & & \\
Gestacional adequacy & 59 & 75.6 & \\
AGA $\dagger$ & 15 & 19.2 & \\
SGA $\ddagger$ & 4 & 5.2 & \\
LGA $\$$ & & & \\
Weight (grams) & 1 & 1.3 & $2251 \pm 363$ \\
$870-1.000$ & 12 & 13.4 & \\
$1.101-1.500$ & 38 & 48.7 & \\
$1.501-2.500$ & 27 & 34.6 & \\
$2.501-4.085$ & & & \\
\hline Sout: & & &
\end{tabular}

Source: Medical records of the infants, ${ }^{*}$ Standard Deviation, $\uparrow$ Adequate for Gestational Age, ‡Small for Gestational Age, §Large for Gestational Age

Predominant among the sample were: Caesarean sections (55-72.3\%), Apgar score at one and five minutes of life $>7$, and gestational age (GA) between 32 and 34 weeks, with moderate classification of the premature (39-50\%) and the term infants ( 23 to $29.4 \%$ ). It was shown that the lowest and highest weight of the neonates was $870 \mathrm{~g}$ and $4085 \mathrm{~g}$, respectively, a mean of $2251 \mathrm{~g}$, with a higher concentration in the range of $1501-2500 \mathrm{~g}$, which characterized an elevated percentage $(48.7 \%)$ of low birth weight infants.

Table 2 - Distribution of the profile of parents/guardians of the infants evaluated with the HINT - Fortaleza, CE, 2010

\begin{tabular}{|c|c|c|c|c|c|}
\hline \multirow{2}{*}{ Variables } & \multicolumn{2}{|c|}{ Mother $(\mathrm{N}=76)$} & \multicolumn{2}{|c|}{ Father $(\mathrm{N}=63)$} & \multirow{2}{*}{$\overline{\mathrm{X}} \pm$ SD } \\
\hline & $\mathrm{n}$ & $\%$ & $\mathrm{n}$ & $\%$ & \\
\hline \multicolumn{6}{|l|}{ Marital status $\dagger$} \\
\hline Consensual union & 43 & 56.6 & 43 & 68.3 & \\
\hline Married & 20 & 26.3 & 20 & 31.7 & \\
\hline Single & 13 & 17.1 & - & - & \\
\hline \multicolumn{6}{|l|}{ Age (in years) } \\
\hline $13-19$ & 16 & 21.0 & 6 & 7.9 & $27.41 \pm 7.67+$ \\
\hline $20-26$ & 31 & 40.8 & 29 & 38.0 & \\
\hline $27-33$ & 17 & 22.4 & 21 & 27.7 & \\
\hline $34-49$ & 12 & 15.8 & 16 & 21.0 & \\
\hline No response & - & - & 4 & 5.3 & \\
\hline \multicolumn{6}{|c|}{ Schooling (in years of study) } \\
\hline Illiterate & - & - & 3 & 3.9 & $12.37 \pm 2.61 \S$ \\
\hline$\leq 10$ & 16 & 21.1 & 18 & 23.7 & $10.30 \pm 3.51 \ddagger$ \\
\hline $11-13$ & 25 & 32.8 & 13 & 17.1 & \\
\hline $14-18$ & 35 & 46.1 & 35 & 46.1 & \\
\hline No response & - & - & 7 & 9.2 & \\
\hline
\end{tabular}

Continue...

\begin{tabular}{|c|c|c|c|c|c|}
\hline \multirow{2}{*}{ Variables } & \multicolumn{2}{|c|}{ Mother $(\mathrm{N}=76)$} & \multicolumn{2}{|c|}{ Father $(\mathrm{N}=63)$} & \multirow{2}{*}{$\bar{X} \pm \mathbf{D P}$} \\
\hline & $\mathrm{n}$ & $\%$ & $n$ & $\%$ & \\
\hline \multicolumn{6}{|l|}{ Employed } \\
\hline No & 54 & 71.0 & 5 & 8.0 & \\
\hline Yes & 22 & 29.0 & 58 & 92.0 & \\
\hline \multicolumn{6}{|c|}{ Income (Minimum) } \\
\hline$<1$ & 13 & 17.1 & & & \\
\hline $1-2$ & 53 & 69.7 & & & \\
\hline $3-4$ & 10 & 13.2 & & & \\
\hline \multicolumn{6}{|l|}{ Race } \\
\hline Brown & 52 & 68.4 & 56 & 73.7 & \\
\hline White & 16 & 21.0 & 15 & 19.7 & \\
\hline Black & 8 & 10.5 & 5 & 6.6 & \\
\hline
\end{tabular}

Source: Data collected by means of the HINT, * Standard Deviation, $\dagger$ Father $\ddagger$ Parents $\S$ Mother.

Consensual unions predominated (43-56.6\%), as did mothers (76) over fathers (63), because some did not live with the father of the child. The age of parents indicated a young group, with a higher proportion of mothers (31 $-40.8 \%$ ) encountered between 20 and 26 years of age, with $16(21 \%)$ adolescents, with a mean of 25.61 years of age. In relationship to fathers, the extremes were 17 and 49 years, with a mean of 27.41 years of age, with a higher concentration (38.1\%) in the age range of $20-26$ years of age.

The schooling of fathers emphasized middle school, which coincides with the results of the mothers, presenting a mean years of study of 10.30 and 12.37 , respectively. On the occupation item, 54 (71\%) mothers mentioned being at home, the remainder performed paid activities such as retailers (5), seamstresses (4), operational auxiliaries (3), teachers (3), confectioners (3), hairdressers (2), and cleaners (2). In relationship to fathers, 53 (69.7\%) exercised various functions such as delivery, porters, general service, sales clerk, waiter, pizza chef, mechanic, and machine operator. Five (7.4\%) found themselves unemployed. These families survived on an income equivalent to one to two minimum wages and, $13(17.1 \%)$ with less than one. Regarding race of the parents, the color brown predominated.

Tables 3 and 4 feature the evaluation of neuromotor development of the children by mean total scores. In the evaluation of the examiners, the children were distributed into two groups: preterm and term.

Table 3 - Distribution of total mean scores of the infants in three evaluations - Fortaleza, CE, 2010

\begin{tabular}{|c|c|c|c|c|}
\hline \multicolumn{2}{|c|}{ Evaluation / Examiner } & $\begin{array}{c}\text { Preterm } \\
\bar{X} \pm \mathbf{D P}\end{array}$ & \multirow{2}{*}{$\begin{array}{c}\text { Term } \\
\bar{X} \pm \mathbf{D P} \\
24.7 \pm 9.6\end{array}$} & \multirow{2}{*}{$\begin{array}{r}\mathbf{p}^{*} \\
0.856\end{array}$} \\
\hline 1st Eval. $\$$ & $\mathrm{EX} 1^{\S}$ & $25.2 \pm 11.1$ & & \\
\hline & $\mathrm{EX} 2^{\|}$ & $23.8 \pm 10.9$ & $23.8 \pm 9.6$ & 0.993 \\
\hline & EX3" & $24.0 \pm 10.9$ & $23.9 \pm 9.9$ & 0.985 \\
\hline \multirow[t]{3}{*}{ 2nd Eval. } & EX1 & $24.0 \pm 10.5$ & $23.7 \pm 9.1$ & 0.906 \\
\hline & $\mathrm{EX} 2$ & $23.0 \pm 10.5$ & $22.9 \pm 9.0$ & 0.959 \\
\hline & EX3 & $23.1 \pm 9.9$ & $22.8 \pm 9.3$ & 0.895 \\
\hline \multirow[t]{3}{*}{ 3rd Eval. } & EX1 & $14.8 \pm 10.2$ & $11.6 \pm 6.9$ & 0.181 \\
\hline & EX2 & $14.7 \pm 10.2$ & $11.1 \pm 6.8$ & 0.137 \\
\hline & EX3 & $14.6 \pm 10.1$ & $11.8 \pm 6.9$ & 0.220 \\
\hline
\end{tabular}


A variation of 14.6 to 25.2 and 11.8 to 24.7 was observed for children born preterm and term, respectively.

The mean, in the first and in the second evaluation, did not present significant changes in the groups (preterm and term), however, in the third, the mean of each examiner of the preterm infants was more of that those born at term. That said, the difference did not present statistical significance.

In agreement with the final scores of the HINT: Advanced, Normal, Suspect and Abnormal(8), there was evidence of advanced and normal scores in a majority of children born prematurely and at term, in the first and in third evaluation, classified with good neuromotor performance.

It was also observed that three examiners identified suspect and abnormal scores of children born prematurely and at term. In the meantime, it is highlighted that in the third evaluation, the progress of the term infant who had suspect scores reached normal scores, while seven premature infants maintained suspect and abnormal scores. In this evaluation, the first and third examiner elected four premature children with abnormal scores, and the second examiner selected three premature infants. By the analysis of scores, the groups did not present significant differences.

Table 4 - Classification of the development of preterm and term infants regarding scores achieved in the first and third evaluation Fortaleza, CE, 2010

\begin{tabular}{|c|c|c|c|c|c|c|c|c|c|c|c|}
\hline \multirow{2}{*}{\multicolumn{2}{|c|}{ Evaluation/Examine }} & \multirow[t]{2}{*}{ Group } & \multicolumn{2}{|c|}{ Advanced } & \multicolumn{2}{|c|}{ Normal } & \multicolumn{2}{|c|}{ Suspect } & \multicolumn{2}{|c|}{ Abnormal } & \multirow{2}{*}{$\mathbf{p}^{*}$} \\
\hline & & & $\mathbf{n}$ & $\%$ & $\mathbf{n}$ & $\%$ & $\mathbf{n}$ & $\%$ & $\mathbf{n}$ & $\%$ & \\
\hline \multirow[t]{6}{*}{ 1stEval. $\dagger$} & EX1\% & $\begin{array}{l}\text { PT } \\
\end{array}$ & 13 & 23.6 & 35 & 63.6 & 3 & 5.5 & 4 & 7.3 & 0.153 \\
\hline & & $\mathbf{T} * *$ & 6 & 26.1 & 13 & 56.5 & 4 & 17.4 & - & - & \\
\hline & EX2§ & PT & 16 & 29.1 & 32 & 58.2 & 4 & 7.3 & 3 & 5.5 & 0.269 \\
\hline & & $\mathbf{T}$ & 5 & 21.7 & 14 & 60.9 & 4 & 17.4 & - & - & \\
\hline & EX3 $\|$ & PT & 17 & 30.9 & 33 & 60.0 & 2 & 3.6 & 3 & 5.5 & 0.122 \\
\hline & & $\mathbf{T}$ & 6 & 26.1 & 13 & 56.5 & 4 & 17.4 & - & - & \\
\hline \multirow[t]{6}{*}{ 3rd Eval. } & EX1 & PT & 17 & 30.9 & 31 & 56.4 & 3 & 5.5 & 4 & 7.3 & 0.397 \\
\hline & & $\mathbf{T}$ & 6 & 26.1 & 17 & 73.9 & - & - & - & - & \\
\hline & EX2 & PT & 16 & 29.1 & 32 & 58.2 & 4 & 7.3 & 3 & 5.5 & 0.392 \\
\hline & & $\mathbf{T}$ & 6 & 26.1 & 17 & 73.9 & - & - & - & - & \\
\hline & EX3 & PT & 16 & 29.1 & 32 & 58.2 & 3 & 5.5 & 4 & 7.3 & 0.392 \\
\hline & & $\mathbf{T}$ & 6 & 26.1 & 17 & 73.9 & - & - & - & - & \\
\hline
\end{tabular}

\section{DISCUSSION}

The majority of evaluation instruments, in clinical practice, education and research, are administered in countries with a sociocultural reality quite distinct from that in which they were conceived, which justified the importance of the process of translation and adaptation, aiming to minimize diversities, in search of cultural equivalence of the actual population ${ }^{(9)}$. It becomes relevant to know the primary qualities of instruments, such as the reliability and validity ${ }^{(11)}$.

Studies about of evaluation of the child, with use of motor scales, show some degree of influence of risk factors and possible deviations to be identified, for treatable conditions or the prevention of complications ${ }^{(5,7,12)}$, that potentially improve the prognosis of the child. It can therefore be verified that there is minimal use in services that perform the monitoring of low or high risk children.

Among the factors related to the risk for alterations in development, pregnancy, labor, conditions of birth, such as prematurity and birth weight, increase the probability of deficits in infant development. Preterm newborn infants present a higher risk of delay in psychomotor development than those born at term ${ }^{(12)}$. Premature birth is not an isolated event, it is accompanied by complications and adverse conditions for the health of the neonate, in addition to the ambience and period of hospitalization. Thus, suspicion of delay should be identified early, beginning in the neonatal period.

Research that addresses conditions of birth and the influence of multiple risk factors reveals incidences and neurodevelopmental sequelae that interfere significantly in the quality of life and social inclusion ${ }^{(4-5,13)}$. A recent study reported that the results about infant development translate to the rate of development of the country, as well as those of education, health conditions and level of attention to health ${ }^{(5)}$. By the evidence, it becomes necessary to obtain knowledge of the reality and of the conditions of the child integrated within the universe of his caregivers.

Biomedical and environmental factors influence, positively or negatively, risk of development of the child, in the first year of life, as well as in interventions centered on the family ${ }^{(14)}$. The child is born with inherited potential for intellectual growth, and this develops through interactions between the environment and family life $\mathrm{e}^{(12)}$. All in all, it is essential to identify the affective biopsychosocial risks on development and to clarify for the parents about judicious attention to the child, within the family context, with emphasis on general aspects of health.
Evaluation of neuromotor development by means of the Harris Infant Neuromotor Test Lopes MMCO, Cardoso MVLML 
In this study the profile of the family (parents/caregivers) featured a primarily young group, with incomplete schooling, that was demonstrated to be less than the ideal school life, since within Brazil, basic education exists (preschool, elementary and middle school), with a duration of eighteen years.

With regard to the socioeconomic conditions of the families, mothers did not refer to paid occupation, homemakers were predominate, with the minority in low salary roles. It is recognized that the insertion of women into the labor market, formally and informally, has not expanded. The parents emphasized occupation in unstable services: delivery, porters, general services, and sales clerks, who survived with a monthly income of one to two minimum wages.

In a study conducted in Canada, to evaluate the neuromotor development of 412 term infants, mothers had a mean age of 29.4 years, $39.8 \%$ with a higher level of education, and $36.2 \%$, incomplete secondary schooling ${ }^{(15)}$. In comparison, in the data of this study, the educational level of mothers was relatively high to that of Brazil, which portrayed a differentiated cultural, educational and behavioral profile, in basic care of health of the child, with impact on infant development.

A recent study in Fortaleza-CE, Brazil, used the HINT in 50 children of three to 12 months of age and 50 parents/ guardians. Results showed that the mean age of mothers was 24.5 years, 23 (46\%) were in a stable union, $16(32 \%)$ with incomplete middle school, and 27 (54\%) families with income between $\mathrm{R} \$ 464.72$ and $\mathrm{R} \$ 929.44^{(6)}$. Those social factors that involve the infant represent a reality with significant difficulties for offering the necessary care, which impacts development.

In research, particular attention should be paid regarding developed and developing countries, because there are those economic and politically organized countries, with a better standard of life, with conditions favorable to promotion and to monitoring of the health of the child in a general manner.

Tables 3 and 4 refer to evaluation properly stated, in that the children were distributed in groups: those born prematurely and at term. According to the age ranges that consist in the HINT, the chronological age of children prevailed between four months and 16 days - five months and 15 days to eight months and 16 days - nine months and 15 days. In relationship to corrected age, variation occurred between three months and 16 days - four months and 15 days to seven months and 16 days - eight months and 15 days.

To the final of the three consecutive evaluations, under the view of each examiner, the mean of total scores for the preterm and the term child were shown to be 14.625.2 and 11.8 - 24.7, respectively. The mean of the scores was similar between the groups, in the first and second evaluation. Only in third was a difference identified between the means of the premature infants in relationship to those born at term, however the difference did not show statistical significance with the many evaluations.

A study with 73 children, applying the Brazilian version of the HINT, showed an excellent reliability index on the total score, characterizing it as a reliable support tool in infant evaluation. Children with advanced and/ or normal scores were identified, considering that the study only contemplated supposedly healthy children (6.11), different than the current study, conducted with at-risk children.

The scores achieved showed a higher percentage of children born premature and at term with advanced scores and those of normality, what is considered good performance in the neuromotor development. In the meantime there were suspect and abnormal scores of premature and term infants, in the first and third evaluation, that warned of delay and implications of lower than desired development.

The neuromotor behavior of the age range did not correspond in the items for postural antigravity control, extension of passive movement in pronation, and showed as possibly compromised, in one child, who did not demonstrate visual tracking. In these circumstances, the child born at term and preterm presented progression of postural control in a sequential manner, in the first three months of life, and in relationship to the level of motor ability in supine and prone position, presented improvement in competence of movements, developing in a slower manner ${ }^{(16)}$.

As the research elapsed, progression was noticed in the third evaluation, in that there was a decrease in suspect scores, in that the term child achieved scores of a normal pattern. Thus, seven premature infants remained with suspect and abnormal scores, highlighting alterations, such as hypotonic or hypertonic posture and visual difficulty. Among the children with abnormal scores, one daughter of an adolescent drug user stood out. The use of drugs by pregnant women is a biological risk factor little acknowledged in the neonatal period ${ }^{(5)}$.

Through the deviations in development, children were referred for complementary examinations and definition of a clinical diagnosis. In addition, the parents / guardians were given clarification regarding the alterations and future interventions in specialty services, in the perspective of better quality of life for the child and family.

The results allowed more approximation with the family for enlightening them about their effective participation in the process. Four parents reported the knowledge of deviations, as well as accompanying the child to qualified professionals, in the area of attention to infant development. Three, however, were unaware of any type of developmental delay of the child. 
Studies about the monitoring of infant development, in follow-up programs ${ }^{(4,6,17)}$, refer that the families can count on support for orientation, constituting a factor of protection to the infant development. Furthermore, the implementation of follow-up is recommended, however the network of assistance provided to the infant discharged from the NICU is deficient in the country ${ }^{(17)}$.

All in all, the evaluation of infant development, recommended by the Ministry Health, as part of the basic health care, and of the nurse, in the childcare consultation, uses the Health of the Child booklet as an instrument of assessment and detection of delays in the development of the infant ${ }^{(18)}$ which, when identified early, increases the chances of the deviations being corrected or attenuated. Parents and family should be oriented in the promotion of a safe environment, so that the child can reach his potential for development ${ }^{(17-18)}$.

In this context, the importance of the involvement of the parents is recognized, in harmony and understanding, for full development and well-being of the child.

\section{CONCLUSION}

The HINT was administered in the evaluation of neuromotor development, in the first year of life, and through it, standards of normality were identified that characterized

\section{REFERENCES}

1. Oliveira MMC, Almeida PC, Cardoso MVLML. Growth of premature children with very low weight coming from the neonatal unit: descriptive study. Online Braz J [Internet]. 2009 [cited 2014 Jan 27]];8(1). Available from: http://www.objnursing.uff. br/index.php/nursing/article/view/2256

2. Formiga CKMR, Linhares MBM. Assessment of preterm children's early development. Rev Esc Enferm USP. 2009;43(2):472-80.

3. Willrich A, Azevedo CCF, Fernandes JO. Desenvolvimento motor na infância: influência dos fatores de risco e programas de intervenção. Rev Neurocienc. 2009;17(1):51-6.

4. Giachetta L, Nicolau CM, Costa APBC, Zuana AD. Influência do tempo de hospitalização sobre o desenvolvimento neuromotor de recém-nascidos pré-termo. Fisioter Pesqui. 2010;17(1):24-9.

5. Brito CML, Vieira GO, Costa COM, Oliveira NF. Desenvolvimento neuropsicomotor: o teste de Denver na triagem dos atrasos cognitivos e neuromotores de pré-escolares. Cad Saúde Pública. 2011;27(7):1403-14. good neuromotor performance, as well as the possible risks / deviations. Furthermore, it afforded the approximation with the family reality, which refers to the influencing aspects of the development of the child.

In the analysis of the profile of the parents/guardians, a young group predominated, for the most part, with incomplete schooling, in a consensual union, with income below or equal to two times the minimum wage. Among the risk factors that can influence future development of the child, the gestational period, delivery, conditions of birth, as well as the socioeconomic and cultural context were highlighted.

The evaluation of the development of 78 children, in the age range of two months and 15 days to 12 months and 15 days, indicated positive results of the progression trajectory of the child in the first year of life. The child with advanced or normal scores demonstrated motor behavior, according to the development milestones. In the meantime, three children with suspect or abnormal scores were considered at risk, who then required judicious evaluation for diagnostic purposes, a circumstance that enabled nursing interventions, with referral to specialized service of neuromotor stimulation (follow-up).

The limitations of study included the type of sample (convenience) and the fact that it was performed with parents of children discharged from one public maternity unit of the State.

6. Cardoso MVLML, Maia PC, Silva LP, Silva GRF, Hayes VE, Harris SR. Infant development and parents' perceptions associated with use of the Harris Infant Neuromotor Test. Rev RENE. 2010;11(n. esp):124-32.

7. Nascimento R, Piassão C. Avaliação e estimulação do desenvolvimento neuropsicomotor em lactentes institucionalizados. Rev Neurocienc. 2010;18(4):469-78.

8. Harris SR, Backman CL, Mayson TA. Comparative predictive validity of the Harris Infant Neuromotor Test and the Alberta Infant Motor Scale. Dev Med Child Neurol. 2010;52(5):462-7.

9. Tse L, Mayson TA, Leo S, Lee LLS, Harris SR, Hayes VE, et al. Concurrent validity of the Harris Infant Neuromotor Test and Alberta Infant Motor Scale. J Pediatr Nurs. 2008;23(1):28-36.

10. Silva GRF, Cardoso MVLML. Confiabilidade intraclasse do Harris Infant Neuromotor Test na língua portuguesa: utilização com crianças brasileiras. Cultura Cuidado. 2011;15(30):60-70.

11. Silva LP, Maia PC, Lopes MMCO, Cardoso MVLML. Intraclass reliability of the Alberta Infant Motor Scale in the Brazilian version. Rev Esc Enferm USP. 2013;47(5):1046-51.
Evaluation of neuromotor development by means of the Harris Infant Neuromotor Test Lopes MMCO, Cardoso MVLML 
12. Novato TS, Grossi SAA, Kimura M. Cultural adaptation and validation of the "Diabetes Quality of Life for Youths" measure of Ingersoll and Marrero into Brazilian culture. Rev Latino Am Enfermagem. 2008;16(2):224-30.

13. Manacero S, Nunes ML. Avaliação do desempenho motor de prematuros nos primeiros meses de vida na Escala Motora Infantil de Alberta (AIMS). J Pediatr. 2008;84(1):53-9.

14. Wiese EBP. O desenvolvimento do comportamento do bebê prematuro no primeiro ano de vida. Psicol Reflex Crit. 2009;22(1):76-85.

15. Grantham-Mcgregor S. International child development steering group. Developmental potential in the first 5 years for children in developing countries. Lancet. 2007;369(9555):60-70.
16. Megens AM, Harris SR, Backman CL, Hayes VE. Knowngroups analysis of the Harris Infant Neuromotor Test. Phys Ther. 2007;87(2):164-9.

17. Ferraz ST, Frônio JS, Neves LAT, Demarchi RS, Vargas ALA, Ghetti FF, et al. Programa de Follow-up de recém-nascidos de alto risco: relato da experiência de uma equipe interdisciplinar. Rev APS. 2010;13(1):133-9.

18. Santos MEA, Quintão NT, Almeida RX. Avaliação dos marcos do desenvolvimento infantil segundo a estratégia da atenção integrada às doenças prevalentes na infância. Esc Anna Nery Rev Enferm. 2010;14(3):591-8. 